\title{
LUMINESCENCE DATING OF THE MORASKO (POLAND), KAALI, ILUMETSA AND TSÕÕRIKMÄE (ESTONIA) METEORITE CRATERS
}

\author{
WOJCIECH T.J. STANKOWSKI ${ }^{1}$, ANTO RAUKAS ${ }^{2}$, ANDRZEJ BLUSZCZ ${ }^{3}$ \\ and STANISLAW FEDOROWICZ ${ }^{4}$ \\ ${ }^{1}$ Institute of Geology, Adam Mickiewicz University, \\ Maków Polnych 16, 61-606 Poznań, Poland \\ ${ }^{2}$ Institute of Ecology, Tallinn University, \\ Uus-Sadama 5, 10120 Tallinn, Estonia \\ ${ }^{3}$ Institute of Physics, Silesian University of Technology \\ Krzywoustego 2, 44-100 Gliwice, Poland \\ ${ }^{4}$ Institute of Geography, Department of Geomorphology and Quaternary Geology \\ Dmowskiego 16A, 80-950 Gdańsk, Poland
}

\begin{abstract}
The TL dating of sinter crust of Morasko meteorites proves that the extraterrestrial matter fell about 5000 yr BP. Similar data were obtained for the Kaali impact. The OSL analyses show incomplete bleaching of old rock material especially in the Estonian craters. Almost all data obtained for the immediate impact area indicate ages younger than the Quaternary morphogenesis. The method used seems promising for determining the age of impacts and the origin of small depressions of unknown genesis.
\end{abstract}

Keywords: TL dating, OSL dating, impact craters, Poland, Estonia.

\section{INTRODUCTION}

Preliminary pilot studies of luminescence dating have been carried out for two well-known crater sites - the Morasko Meteorite Reserve near Poznań, Poland and the Kaali meteorite area on the Island of Saaremaa, Estonia (Stankowski, 2007). The data show that the TL and OSL luminescence tests are promising for determining the time of a meteorite impact as well as the origin of craters. The pilot experiments were therefore continued with measurements of the sinter crust of Morasko meteorites and of samples from meteorite craters of Ilumetsa and Tsõõrikmäe. The results show that the luminescence of quartz grains in older strata is bleached during the impact to different degrees, i.e., from complete bleaching to partial or no bleaching at all.

\section{LOCATION AND GEOLOGY OF SITES}

The Moraska Góra hills received their final form dur-

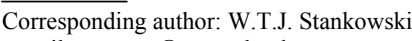

e-mail: stawgeo@amu.edu.pl ing the Poznan stage of the last glaciation, about $18,000 \mathrm{yr}$ BP. The hills are composed of strongly glacitectonically deformed Quaternary and Neogene deposits. The morphology of the hills and the area around them is characterized by abundant depressions of evorsive and glaciokarstic origin. Permafrost affected them not later then 10,000 yr BP. Since then the depressions have been filled, mainly with organic matter (Stankowski, 2001). Near the top of Moraska Góra, on its north-east slope, six meteorite craters occur. Palynological analyses of the organic infillings in two craters (crater A which is $90 \mathrm{~m}$ in diameter and $11.5 \mathrm{~m}$ deep, and crater $\mathrm{C}$ which is $30 \mathrm{~m}$ in diameter and $4.3 \mathrm{~m}$ deep), have been carried out by Tobolski (1976) and have been confirmed by Milecka (pers. comm., 2005). The accumulation in craters started not earlier than in the middle of the Atlantic period, some 5500-5000 yr BP. This palynological estimation was checked recently by ${ }^{14} \mathrm{C}$ dating of samples from craters A and $\mathrm{B}$ (the latter being $50 \mathrm{~m}$ in diameter and $9 \mathrm{~m}$ deep). The obtained ages are 4495 \pm 35 (Poz-18863; 4980-5300 cal BP) and 4760 \pm 40 (Poz-18960; 5320-5600 cal BP), respectively. It should be mentioned that kettle-holes, situated about $30 \mathrm{~km}$ north of Morasko (Szlaban near 
Oborniki) along the plausible trajectory of the meteorite impact, contain a peat layer (at the depth $100-80 \mathrm{~cm}$ ) that has been dated as 5070 \pm 40 (Poz-7005; 5720-5920 cal $\mathrm{BP})$ at the bottom, and as $4750 \pm 40$ (Poz-7004; 5320-5590 cal BP) at the top, and that this peat layer shows a relatively high concentration of magnetic spherules (Stankowski et al., 2006). In our opinion it is synchronous with the Morasko meteorite fall. Anyway all data indicate that the Morasko impact craters are geologically young. The topographic and morphogenetic situation of Morasko and Szlaban sites were presented in two papers (Stankowski, 2001; Stankowski et al., 2006).

The Estonian sites are situated in a different geological and geomorphological setting (their geological and topographical situation were discussed in several papers Reinvald, 1933; Tiirmaa, 1994; Raukas et al., 2001; Raukas, 2002). The Kaali craters, nine together, on the Island of Saaremaa have been formed in Silurian dolomites covered by a thin Quaternary stratum (Reinvald, 1933; Tiirmaa, 1994; Raukas et al., 2005). The largest crater has a diameter $110 \mathrm{~m}$ and is occupied by a small lake, named Lake Kaali. The diameter of the lake depends on the seasonal water level and ranges from 30 to $60 \mathrm{~m}$. The water depth is $1-6 \mathrm{~m}$, and the maximum thickness of the lake sediments is $5.8 \mathrm{~m}$. The smaller craters, locally known as dry lakes, are 1-4 m deep hollows with diameters between 12 and $14 \mathrm{~m}$. Probably several small craters may remain undiscovered.

The glacial topography in this area developed more than 11,700 yr BP (Marini et al., 2004; Raukas, 2004; Raukas and Stankowski, 2005). A large part of Saaremaa was flooded by the waters of the Baltic See during the Early Holocene but during the last 8000 years the Kaali area no longer has been in the marine realm. The age of the Kaali meteorite impact is still under discussion; range from more than 7500 to $1500 \mathrm{yr} \mathrm{BP}$, but considering palynological analyses and the radiocarbon dates on craters' infillings, the craters are at least $4000 \mathrm{yr}$ old (Raukas and Laigna, 2005; Raukas et al., 2005).

The Ilumetsa and Tsõõrikmäe impact sites are both situated in the south-eastern part of Estonia, where the glacial relief was created some 13,000 yr ago (Raukas, 2004; Raukas and Stankowski, 2005). The thicknesses of the Quaternary sediments that cover Middle -Devonian sandstones, are between a few and a few dozen of meters. At Ilumetsa, at least three craters are present. Põrguhaud, the largest one, has a diameter of $75-80 \mathrm{~m}$ at the top of the uplifted rim, and is $12.5 \mathrm{~m}$ deep. The crater is partly filled with a thin layer of gyttja and peat that is up to $2 \mathrm{~m}$ thick. Radiocarbon ages of $6030 \pm 100$ (TA-310; 6600$7250 \mathrm{cal} \mathrm{BP}$ ) and $5910 \pm 100$ (TA-752; 6450-7000 cal BP) yr BP from the lowermost organic layer and palynological evidence suggest that the impact took place some $7000{ }^{14} \mathrm{C}$ yr BP. Not far to South of Põrguhaud the next crater is present; it is $\sim 60 \mathrm{~m}$ in diameter and $\sim 10 \mathrm{~m}$ deep, but does not show rim walls. Its bottom is covered by $\sim 2$ $\mathrm{m}$ thick sandy diluvium. Investigation of glassy spherules in nearby Meenikunno bog suggest, that the Ilumetsa craters were formed about $6600 \mathrm{yr}$ ago (Raukas et al., 2001).

The oldest meteorite crater of the Quaternary age in Estonia is located at Tsõõrikmägi near Räpina town (see
Raukas, 2002). Its mound is flattened, but a ring structure is well preserved. The diameter of the crater at the top of the mound is $38-40 \mathrm{~m}$, and its depth from the highest point of the rim is $5.5 \mathrm{~m}$. The crater is located in the reddish-brown basal till. The peat in the depression is $4.5 \mathrm{~m}$ thick and, according to the palynological and radiocarbon data, the age of the crater is about 9500 yr (Raukas, 2002).

\section{THE LUMINESCENCE DATING}

The impact dates obtained earlier were verified by optically stimulated luminescence (OSL) and thermoluminescence (TL) dating, to establish the ages of the last events zeroing luminescence signal of the quartz grains. The high temperatures and pressures occurring during the meteorite impact should induce bleaching and the luminescence ages should therefore coincide with the ages of the craters.

The cores of the organic infilling and the mineral substratum were recovered from the two Morasko craters thanks to the co-operation with the GeoForschungsZentrum in Potsdam, where the cores were also examined. The bottom of Crater A consists of deformed Neogene sediments ("Poznań Series", not younger than 5 million yr) and that of Crater B consists of Quaternary sediments (not younger than 18,000 yr BP; probably much older in fact).

The OSL ages of 101 individual aliquots of quartz extracts from the crater's bottom material were established by means of the SAR protocol (Stankowski, 2007). The distribution of ages is given in Fig 1.

The OSL results thus indicate a bleaching event not before 10,000 yr BP. As seen from the distribution, the bleaching did not affect all the grains to the same extent and some still have a part of the luminescence acquired before. This should be kept in mind as an important factor influencing the dating results and their interpretation.

The TL dating method was applied to the sinter crust of Morasko meteorites. This very resistant meteorite "skin" (a few millimetres to a few centimetres thick),

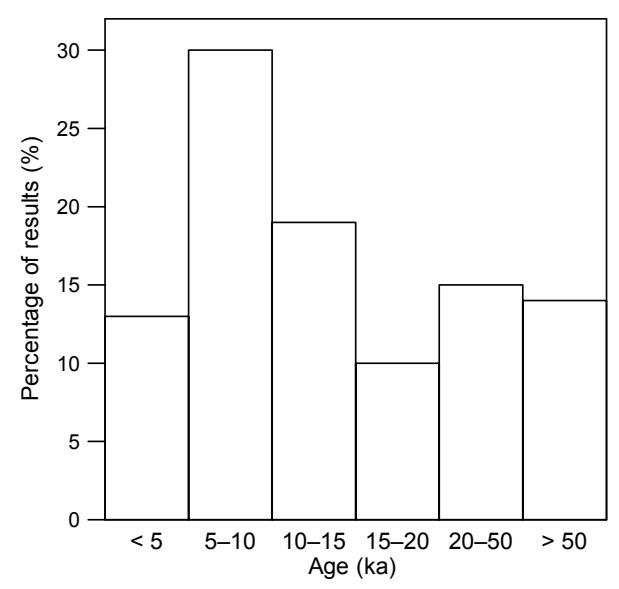

Fig. 1. The distribution of the ages of aliquots. A total number of 101 quartz aliquots from bottom sediments of both craters have been dated. Each aliquot consisted of ca. $0.5 \mathrm{mg}$ of quartz grains of the size between 125-200 $\mu \mathrm{m}$. 
being the effect of increased temperature and later weathering processes in the substratum rocks, was sampled from four meteorites of different sizes (Table 1).

The obtained TL ages of the four meteorite skins are the same within the reported uncertainties, yielding an average value of $5.25 \pm 0.60 \mathrm{ka}$. This is consistent with the previous palynological and radiocarbon age evaluations for the Morasko Meteorite fall (Stankowski, 2001, Stankowski et al., 2006), and with the OSL results presented above.

The Estonian sites of the meteorite craters in Kaali, Ilumetsa and Tsõõrikmäe were dated by both TL and OSL methods. For the TL dating the multiple-aliquot regenerative-dose protocol was applied, whereas the single-aliquot regenerative-dose (SAR) protocol was applied for the OSL dating (see Tables 2-4 for results). Independent data (Raukas and Stankowski, 2005) estimate the age of the glacial relief (after ice sheet recession) at these sites to $11.7 \mathrm{ka}, 13.0 \mathrm{ka}$ and $13.0 \mathrm{ka}$ respectively.

OSL SAR results obtained for aliquots extracted from sample EeKal c 2/8(37) from crater 2/8 were very much scattered - 12 ages range from $4.66 \pm 0.18$ to $32.8 \pm 1.2 \mathrm{ka}$ with traces of concentration around $8.70 \pm 0.78 \mathrm{ka}$. The scatter is also visible in the TL dating result burdened with a higher uncertainty (methodological problems have been discussed in Fedorowicz, 2006).

Most quartz grains from samples of the Ilumetsa craters were poorly bleached. The OSL age of the glacial sediment from the immediate surrounding of the Main Crater (EeIl 4/25) predates the ice sheet recession and is related to the preceding exposure of quartz grains to light. The OSL results obtained on single aliquots of quartz extracts from samples of disintegrated sandstone (EeIl s 2/12, EeIl s 2/14, EeIl r 5/28) are distributed between 50 and $200 \mathrm{ka}$ and show a distinct concentration around $100-130 \mathrm{ka}$ that is probably not relevant to the meteorite impacts. Only two samples, namely EeIl 3/23 and EeIl cs $1 / 4$, yield OSL ages that may be related to the fall of meteorites. The first of the two is the only sample bleached relatively well; the SAR results are contained within a range from $8.11 \pm 0.71$ to $15.4 \pm 1.5 \mathrm{ka}$.
Table 1. TL ages of "metskin" material - approximate time of the fall.

\begin{tabular}{|c|c|c|c|c|}
\hline \multirow{2}{*}{ Information } & \multicolumn{4}{|c|}{ Meteorite } \\
\hline & 1 & 2 & 3 & 4 \\
\hline $\begin{array}{l}\text { Date of } \\
\text { finding }\end{array}$ & $\begin{array}{l}\text { Sept. 11, } \\
2006\end{array}$ & $\begin{array}{l}\text { Sept. 22, } \\
2006\end{array}$ & $\begin{array}{l}\text { Oct. 5, } \\
2006\end{array}$ & $\begin{array}{l}\text { Sept. 26, } \\
2006\end{array}$ \\
\hline $\begin{array}{l}\text { Depth below } \\
\text { surface/mass }\end{array}$ & $\begin{array}{l}70 \mathrm{~cm} / \\
164 \mathrm{~kg}\end{array}$ & $\begin{array}{c}55 \mathrm{~cm} / \\
11 \mathrm{~kg}\end{array}$ & $\begin{array}{l}70 \mathrm{~cm} / \\
10.5 \mathrm{~kg}\end{array}$ & $\begin{array}{l}80 \mathrm{~cm} / \\
21 \mathrm{~kg}\end{array}$ \\
\hline $\begin{array}{l}\text { Metskin } \\
\text { material }\end{array}$ & Silty till & Silty till & Silty sand & $\begin{array}{l}\text { Silty sand } \\
\text { and gravel }\end{array}$ \\
\hline $\begin{array}{l}\text { Age in ka and } \\
\text { Lab. number }\end{array}$ & $\begin{array}{c}\mathbf{5 . 2 \pm 0 . 9} \\
\text { (UG-5941) }\end{array}$ & $\begin{array}{c}5.0 \pm 0.7 \\
\text { (UG-5942) } \\
\end{array}$ & $\begin{array}{c}4.7 \pm 0.4 \\
\text { (UG-5943) }\end{array}$ & $\begin{array}{c}6.1 \pm 0.7 \\
\text { (UG-5244) }\end{array}$ \\
\hline
\end{tabular}

The OSL SAR results obtained for samples EeTs st 5, EeTs st 7, EeTs ss 7a show no ages of quartz grains over $12 \mathrm{ka}$, and the probable age of the meteorite fall may be assessed at $3.3 \mathrm{ka}$ (samples EeTs st 5 and EeTs st 7 both have concentrations around this value). On the other hand the remaining three samples yielded no OSL SAR results younger than $20 \mathrm{ka}$ and they date older glacial sediments.

\section{CONCLUSION}

In the case of the Morasko craters, the results of palynological studies and ${ }^{14} \mathrm{C}$ dating of the oldest layers of organic infilling of the craters agree very well with the luminescence ages of the sinter crust of the meteorites. The OSL results also show that a considerable proportion of the quartz grains in the crater bottom material was well bleached.

The obtained luminescence ages in the Kaali area are generally complementary to other estimates of the craters' age obtained during many years study of this extraterrestrial event. The presence of Paleozoic rocks (Silurian dolomites) at the bottoms of the craters does not influence luminescence results.

On the other hand, Devonian sandstones which form the base of the craters in the Ilumetsa and Tsõõrikmäe areas were probably only partly bleached by the meteorite impact, and this influences the luminescence results. From the samples taken in the Ilumetsa crater area, only one - taken from the bottom of the crater - probably

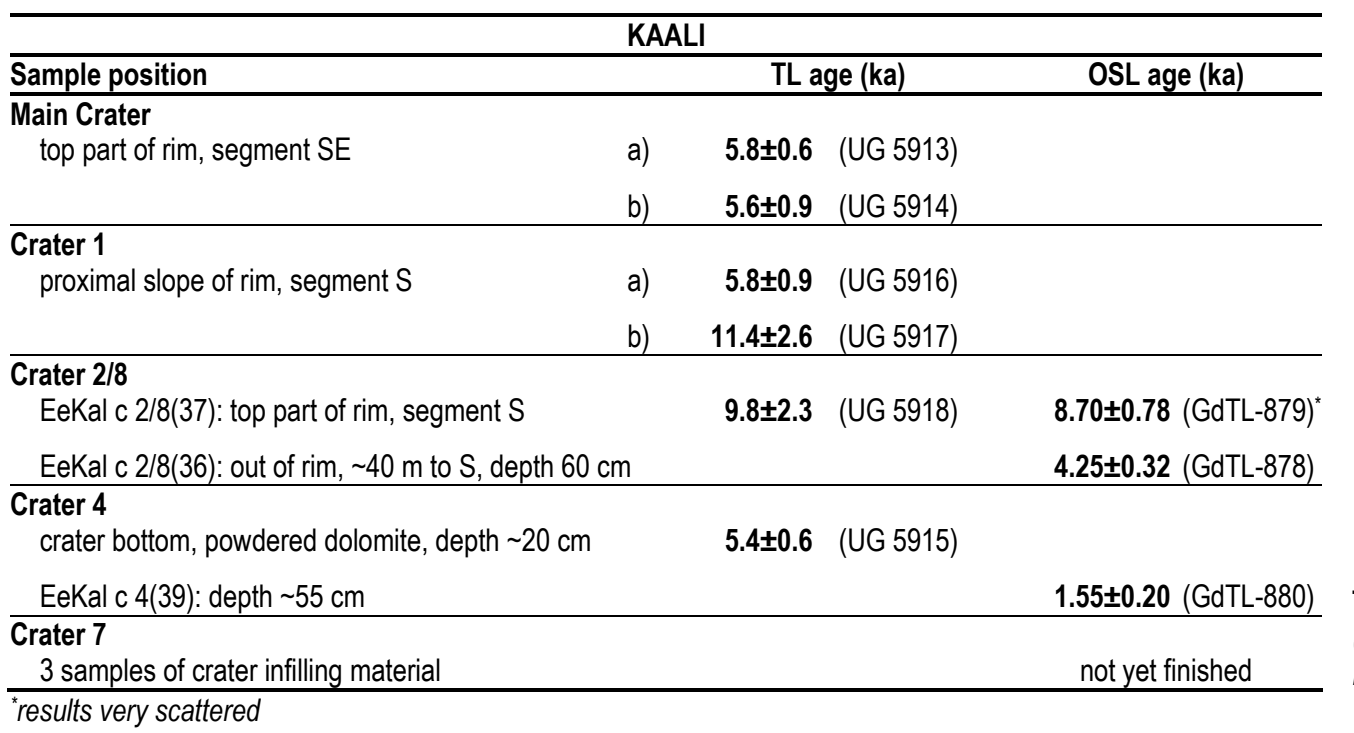

Table 2. Luminescence ages (TL and OSL) of samples from Kaali site. 
Table 3. Luminescence ages (OSL) of samples from llumetsa site.

\begin{tabular}{|c|c|c|}
\hline \multicolumn{3}{|l|}{ ILUMETSA } \\
\hline Sample position & OSL ag & e (ka) \\
\hline $\begin{array}{l}\text { Main Crater - Põrguhaud } \\
\text { Eell 4/25: glacial sediments } \sim 25 \mathrm{~m} \mathrm{NE} \\
\text { from N rim segment, depth } \sim 110 \mathrm{~cm}\end{array}$ & $29.8 \pm 1.6$ & (GdTL-866) \\
\hline $\begin{array}{l}\text { Eell 3/23: material of rim distal lower } \\
\text { part, segment } \mathrm{N} \text {, depth } \sim 140 \mathrm{~cm}\end{array}$ & $9.35 \pm 0.46$ & (GdTL-867) \\
\hline $\begin{array}{l}\text { Eell s 2/12: disintegrated Devonian } \\
\text { sandstone of proximal crater slope, } \\
\text { segment } \mathrm{N} \text {, depth } \sim 130 \mathrm{~cm}\end{array}$ & $127.6 \pm 6.4$ & (GdTL-869) \\
\hline Eell s 2/14: as above, depth $\sim 190 \mathrm{~cm}$ & $126.7 \pm 5.3$ & (GdTL-870) \\
\hline $\begin{array}{l}\text { Eell cs 1/4: crater bottom - disinte- } \\
\text { grated Devonian sandstone, depth } \\
\sim 130 \mathrm{~cm}(\sim 80 \mathrm{~cm} \text { of young organic } \\
\text { sediments with sand below) }\end{array}$ & $7.24 \pm 0.75$ & (GdTL-868) \\
\hline $\begin{array}{l}\text { Põrguhaud S Crater } \\
\text { Eell r 5/28: crater bottom - disinte- } \\
\text { grated Devonian sandstone, depth } \\
\sim 260 \mathrm{~cm}(\sim 220 \mathrm{~cm} \text { of young em- } \\
\text { bankment) }\end{array}$ & $106.9 \pm 3.6$ & (GdTL-871) \\
\hline
\end{tabular}

Table 4. Luminescence ages (OSL) of samples from Tsõõrikmäe site.

\begin{tabular}{|c|c|c|}
\hline \multicolumn{3}{|c|}{ TSÕÕRIKMÄE } \\
\hline Sample position & $\overline{O S L a}$ & (ka) \\
\hline $\begin{array}{l}\text { Tsõõrikmäe Crater } \\
\text { EeTs st } 5 \text { : glacial sediments } \sim 80 \mathrm{~m} \text { to } \\
\mathrm{S} \text { from the rim, segment S, depth } \\
\sim 80 \mathrm{~cm}\end{array}$ & $4.44 \pm 0.25$ & (GdTL-874) \\
\hline EeTs st 6 : as above, depth $\sim 140 \mathrm{~cm}$ & $29.4 \pm 1.7$ & (GdTL-875) \\
\hline $\begin{array}{l}\text { EeTs st } 7 \text { : as above, distal part of the } \\
\text { rim, segment } \mathrm{S} \text {, depth } 30 \mathrm{~cm}\end{array}$ & $1.29 \pm 0.13$ & (GdTL-876) \\
\hline $\begin{array}{l}\text { EeTs t// 3: top part of the rim, seg- } \\
\text { ment S, depth } 60-70 \mathrm{~cm}\end{array}$ & $20.87 \pm 0.87$ & (GdTL-873) \\
\hline $\begin{array}{l}\text { EeTs st/tg 4: as above, depth 100- } \\
110 \mathrm{~cm}\end{array}$ & $48.6 \pm 1.9$ & (GdTL-872) \\
\hline $\begin{array}{l}\text { EeTs ss 7a: top part of the rim, seg- } \\
\text { ment } \mathrm{N} \text {, depth } 130 \mathrm{~cm}\end{array}$ & $3.21 \pm 0.15$ & (GdTL-877) \\
\hline
\end{tabular}

dates the event in agreement with ${ }^{14} \mathrm{C}$ dates. In the case of Tsõõrikmäe crater samples, OSL ages suggest a more recent fall of the meteorite (around $3 \mathrm{ka} \mathrm{BP}$ ) than earlier estimates that were based on palynological and radiocarbon evidence.

The luminescence measurements and dating seem to be a promising method of recognizing small impact craters. Both the material in the crater and the material ejected during the impact have not been bleached completely, and this must be taken into account when interpreting the results. Small meteoritic bodies falling onto loose Quaternary and Neogen deposits do not always produce characteristic features like an impact breccia, high-pressure minerals or glass, so luminescence dating may be the only way of identifying impact craters.

\section{ACKNOWLEDGEMENTS}

The authors are grateful to: Prof. Dr Jorg Negendank and Dr Markus J. Schwab from GeoForschungsZentrum, Potsdam for coring lakes in Morasko meteorite reserve, to Mrs Reet Tiirmaa from Institute of Geology at Tallinn Technical University for help in Kaali, Ilumetsa and Tsõõrikmäe field work, and to Dr hab. Tomasz Goslar from Poznań Radiocarbon Laboratory, as well as to Dr Tom van Loon who read the manuscript and improved the language. The financial support for the research work was provided by the Polish Ministry of Science and Higher Education through the research project No 3 P04E 004 25, and by the Polish Academy of Sciences and the Estonian Academy of Sciences through the EstonianPolish Research Project.

\section{APPENDIX. Laboratory procedures used in lumines- cence dating.}

Quartz grains extraction procedure consisted of following steps:

1) Acid treatment: sediment sample is treated for 24 hours with a $4 \% \mathrm{HCl}$ solution at ambient temperature. The acid treatment was prolonged when necessary to remove all the carbonates.

2) Base treatment: remaining material is treated for 24 hours with a $2 \% \mathrm{NaOH}$ solution at ambient temperature.

These two steps are applied to leach the carbonates and to remove organic matter.

3) Remaining material is rinsed in distilled water and dried at temperature not exceeding $40^{\circ} \mathrm{C}$.

4) Grains are then screened on sieves (mesh sizes 90, $125,200 \mu \mathrm{m})$ and etched with concentrated HF $(40 \%$ $\mathrm{HF}$ for $60 \mathrm{~min}$ at ambient temperature) to remove the outer layer of quartz grains and to dissolve grains of other minerals.

The outermost layer of a grain is exposed to alpha particles that have different efficiency in producing OSL signal than other radiation types. Removing this layer simplifies the dosimetry of grains.

5) Etched grains are rinsed in distilled water and in $4 \%$ $\mathrm{HCl}$ (or $8 \% \mathrm{HNO}_{3}$ ) solution to remove fluorine compounds, and then rinsed again in distilled water before drying.

6) Quartz grains are stored for luminescence measurements.

The single aliquot regenerative dose SAR protocol (Murray and Wintle, 2000) was used in OSL measurements. The SAR protocol cycle consists of six steps.

1) Laboratory irradiation, regenerative dose $D_{i}$.

2) Preheat at $T_{p h}$ for $t_{p h}$ time.

3) OSL measurement at $T_{O S L}$, stimulation for $t_{O S L}$.

4) Laboratory irradiation, test dose $D_{t}$.

5) Preheat at $T_{t p h}$ for $t_{t p h}$ time.

6) OSL measurement at $T_{O S L}$, stimulation for $t_{O S L}$.

Typical values:

$T_{p h}=220^{\circ} \mathrm{C} ; t_{p h}=10 \mathrm{~s}$,

$T_{t p h}=160^{\circ} \mathrm{C} ; t_{t p h}=10 \mathrm{~s}$,

$T_{\text {OSL }}=125^{\circ} \mathrm{C} ; t_{O S L}=30 \mathrm{~s}$, 
$D_{t} \approx 10 \%$ of natural dose but not less than $2-5$ Gy depending on OSL sensitivity.

The cycle is usually repeated for $n=6$ or more times with different regenerative dose values. There is no laboratory irradiation in the first cycle; $D_{0}$ is the natural dose that is to be assessed. The laboratory doses in the next 3 or more cycles, $D_{1}, D_{2}, D_{3}, \ldots$ are chosen for the range to include the natural dose. The dose $D_{n-2}$ is set to zero, to check that the recuperation of the OSL signal is negligible. The last dose $D_{n-1}=D_{1}$ is administered to check the validity of the sensitivity correction using the test dose $D_{t}$.

All the measurements necessary to assess the value of the natural dose absorbed by the grains in the sediment are made on a single aliquot of quartz grains. To do this, about $0.5 \mathrm{mg}$ of grains is fixed to a steel disk with silicon oil.

To increase the reliability of the dating result the protocol is repeated for a number of aliquots.

The multiple aliquot regenerative dose MAR protocol (Wintle and Prószyńska, 1983; Fedorowicz, 2006) was used in TL measurements. The MAR protocol cycle consists of following steps.

1) Laboratory bleaching at $T_{b l}$ for $t_{b l}$ time.

2) Laboratory irradiation, regenerative dose $D_{i}$.

3) Preheat at $T_{p h}$ for $t_{p h}$ time.

4) TL measurement; linear heating at rate $\beta_{T L}$ to the maximum temperature $T_{T L}$.

5) Background TL; linear heating at rate $\beta_{T L}$ to the maximum temperature $T_{T L}$.

Typical values:

$T_{b l}=30^{\circ} \mathrm{C} ; t_{b l}=150 \mathrm{~min}$,

$T_{p h}=220^{\circ} \mathrm{C} ; t_{p h}=10 \mathrm{~s}$,

$\beta_{T L}=5^{\circ} \mathrm{C} / \mathrm{s}$,

$T_{T L}=450^{\circ} \mathrm{C}$.

The cycle is repeated for $n=4$ or more times for different aliquots irradiated with different regenerative doses. The first aliquot is used to measure the effect of the natural dose and it is neither bleached nor irradiated. The next 3 or more aliquots are bleached and irradiated with laboratory doses $D_{1}, D_{2}, \ldots D_{n-1}$ chosen so, that the range includes the expected natural dose.

To increase the precision and reliability of the dating result the protocol is repeated several times and the measurement results are averaged.

Gamma spectrometry was used to establish dose rates for the dated samples. Gamma spectra are taken by means of gamma spectrometers with HPGe semiconductor detectors or with NaI scintillation detectors. Radioactivities of isotopes present in the sediment are calculated by comparing the gamma spectrum recorded for the sample with the spectra recorded for the radioactivity standard and for the detector background. Results are then converted into dose rate values using coefficients published by Adamiec and Aitken (1998) taking into account the average water content in the sediment, quartz grains size and the etching with HF. The contribution of cosmic rays is calculated using the data published by Yokoyama et al. (1982).

\section{REFERENCES}

Adamiec G and Aitken MJ, 1998. Dose-rate conversion factors: update. Ancient TL 16(2): 37-50.

Fedorowicz St, 2006. Metodyczne aspekty luminescencyjnego wieku osadów neoplejstocenskich Europy Środkowej (Methodological Aspects of Luminescence Dating of Central Europe's Neopleistocene Deposits). Gdańsk, Wydawnictwo Uniwersytetu Gdańskiego: $156 \mathrm{pp}$.

Marini F, Raukas A and Tiirmaa R, 2004. Magnetic fines from the Kaali impact-site (Holocene, Estonia): preliminary SEM investigation. Geochemical Journal 38: 107-120.

Murray AS and Wintle AG, (2000) Luminescence dating of quartz using an improved single-aliquot regenerative-dose protocol. $R a$ diation Measurements 32(1): 57-73, DOI 10.1016/S13504487(99)00253-X.

Raukas A, 2002. Postglacial impact events in Estonia and their influence on people and environment. Geological Society of America Special Paper 356: 563-569.

Raukas A, 2004. Application of OSL and ${ }^{10} \mathrm{Be}$ techniques to the establishment of deglaciation chronology in Estonia. Proceedings of the Estonian Academy of Sciences, Geology 53(4): 267-287.

Raukas A and Laigna K-O, 2005. Height of the turbulent gas flow and transport distance of glaas spherules on the example of the Kaali impact, Estonia. Proceedings of the Estonian Academy of Sciences, Geology 54(3): 145-152.

Raukas A, Punning J-M, Moora T, Kestlane Ü and Kraut A, 2005. The Structure and Age of the Kaali Main Crater, Island of Saaremaa, Estonia. In: Koeberl C and Henkel H, eds., Impact Tectonics. Berlin-Heidelberg, Springer-Verlag: 341-355.

Raukas A and Stankowski W, 2005. Influence of sedimentological composition on OSL dating of glaciofluvial deposits: example of Estonia. Geological Quarterly 49: 463-470.

Raukas A, Tiirmaa R, Kaup E and Kimmel K, 2001. The age of the Ilumetsa meteorite craters in southeast Estonia. Meteoritics \& Planetary Science 36: 1507 - 1514.

Reinvald I, 1933. Kaali-jarv - the Meteorite Craters on the Island of Ösel (Estonia). Publications of the Geological Institution of the University of Tartu 30: 182-202.

Stankowski WTJ, 2001. The geology and morphology of the natural reserve „Meteoryt Morasko”. Planetary and Space Science 49(7): 749-753, DOI 10.1016/S0032-0633(01)00011-3.

Stankowski WTJ, Katrusiak A and Budzianowski A, 2006. Crystallographic variety of magnetic spherules from Pleistocene and Holocene sediments in the Northern foreland of Morasko-Meteorite Reserve. Planetary and Space Science 54(1): 60-70, DOI 10.1016/j.pss.2005.08.005.

Stankowski WTJ, 2007. Luminescence dating as a diagnostic criterion for the recognition of Quaternary impact craters. Planetary and Space Science 55(7-8): 871-875, DOI 10.1016/j.pss.2006.11.006.

Tiirmaa R, 1994. Kaali Meteoriit/Kaali Meteorite. Tallinn, Eesti TA Geoloogia Instituut: 104 pp (in Estonian with English, Russian and Finnish summaries).

Tobolski K, 1976. Palynological investigations of bottom sediments in closed depressions, Meteorite Morasko and region of its fall. Uniwersytet im. Adama Mickiewicza w Poznaniu, Seria Astronomia 2: 21-26.

Wintle AG, Prószyńska H, 1983. TL dating of loess in Germany and Poland. PACT 9: 547-554.

Yokoyama Y, Nguyen H-V, Quaeqebeur J-P, Poupeau G, 1982. Some problems encountered in the evaluation of annual dose-rate in the electron spin resonance dating of fossil bones. PACT 6: 105-115. 